\title{
В.Ю. КОРДАБОВСКИЙ
}

\section{Сорт картофеля нового поколения Зоя}

Современные конкурентоспособные сорта картофеля должны иметь лучшее сочетание биоморфологических и хозяйственно ценных признаков, быть максимально адаптированными к эколого-географическому пространству, для которого они создаются. Основная цель нашей селекиионной работы заключается в получении экологически пластичных, приспособленных к специфическим условиям Магаданской области новых генотипов картофеля с унаследованными и закрепленными гибридным потомством ценными хозяйственными признаками: скороспелостью, высокой урожайностью и потребительскими качествами получаемой продукции, устойчивостью к фитофторозу. Правильный выбор генетических источников для селекции с учетом характера наследования в условиях севера Дальнего Востока позволяет получать генотипь с уникальным набором генов, формирующих признаки, необходимые для создания сорта. Один из таких сортов нового поколения - среднеранний сорт Зоя, созданный на базе ФГБНУ Магаданский НИИСХ совместно с ФГБНУ ВНИИКХ им. А.Г. Лорха.

Ключевые слова: картофель, селекция, ценные признаки, генотипы, сорт.

The new generation potato variety Zoya. V.Y. KORDABOVSKY (Magadan Research Agricultural Institute, Magadan).

Modern competitive potato varieties should include the best combination of biomorphological and economically valuable characteristics, and be maximally adapted to the ecological and geographical space for which they are created. The main goal of our selection work is to obtain environmentally plastic, adapted to the specific conditions of the Magadan Region, new genotypes of potatoes with inherited and fixed hybrid offspring valuable economic characteristics: ripeness, high yield and consumer qualities of the resulting products, resistance to late blight. The correct choice of genetic sources for selection, taking into account the nature of inheritance in the North of the Far East, allows you to get genotypes with a unique set of genes that form the characteristics necessary for creating a variety. One such varieties of new generation - mid-season variety Zoya, created on the basis of Magadan Research Agricultural Institute with FSBIS A.G. Lorch Potato Research Institute.

Key words: potato, selection, valuable traits, genotypes, variety.

Поиск, мобилизация и правильный подбор компонентов скрещивания с высоким генетическим потенциалом позитивных биоморфологических и хозяйственно ценных признаков, успешно наследуемых клубневым потомством, позволяет создать современный конкурентоспособный сорт картофеля, отвечающий требованиям потребительского рынка.

На наш взгляд, проводимая в конкретном регионе селекционная работа должна отличаться специфическим зональным характером и экологической целесообразностью. Эколого-генетический подход в селекции картофеля позволяет получить генотипы, устойчивые к стрессовым факторам территории возделывания культуры, более полно изучить и понять закономерности наследования выделенными генотипами ценных признаков в последующих клубневых поколениях [3].

Сорта картофеля нового поколения сочетают в себе более 50 признаков, определяющих скороспелость и продуктивность культуры, структуру и качество клубней, резистентность к распространенным заболеваниям и множество других показателей $[1,8,9]$.

КОРДАБОВСКИЙ Виктор Юрьевич - старший научный сотрудник (Магаданский научно-исследовательский институт сельского хозяйства, Магадан). E-mail: agrarian@maglan.ru 
В работах ряда авторов подчеркивается, что сорта, созданные в определенных экологических условиях, эффективнее наследуют ценные признаки и устойчивость к средовым флуктуациям [2, 4-7].

В Магаданском научно-исследовательском институте сельского хозяйства селекция картофеля с учетом взаимодействия генотипа и среды произрастания растения ведется по трем основным направлениям: раннеспелость, высокая продуктивность и устойчивость к фитофторозу. По мере продвижения селекционного процесса дается оценка стабильности и адаптивности изучаемых генотипов к региональным агроклиматическим условиям. Отбор потомства новых генотипов картофеля по совокупности наследования хозяйственно ценных признаков и экологической пластичности позволяет выделить ряд перспективных гибридных популяций для конкурсного испытания.

Эффективность использования объектов скрещивания во многом зависит от успешного подбора исходных родительских форм. Правильный выбор генетических источников для гибридизации с учетом характера наследования позволяет отобрать потомство новых генотипов картофеля с уникальным сочетанием генов, формирующих качественный набор хозяйственно ценных и биоморфологических признаков.

Но самый надежный критерий эффективности отбора в популяции - создание сорта. В нашем случае подтверждение эффективности скрещивания родительских форм - новый сорт картофеля Зоя.

Характеристика сорта Зоя. Происхождение - Памяти Осиповой $\times$ 946-3. Группа спелости - среднеранний, столового назначения. По заключению ФГБУ «Государственная комиссия Российской Федерации по испытанию и охране селекционных достижений» от 14 октября 2019 г. сорт Зоя явно отличается от любого другого общеизвестного сорта, соответствует требованиям однородности и стабильности (см. таблицу).

Описание селекционного достижения

\begin{tabular}{|c|c|c|c|}
\hline $\begin{array}{l}\text { № } \\
\text { П/ח }\end{array}$ & Признак & Степень выраженности & Индекс \\
\hline 1 & $\begin{array}{c}\text { Световой росток: } \\
\text { размер }\end{array}$ & Средний & 5 \\
\hline 2 & форма & Сферическая & 1 \\
\hline 3 & интенсивность антоциановой окраски основания & От средней до сильной & 6 \\
\hline 4 & доля синевы в антоциановой окраске основания & Средняя & 2 \\
\hline 5 & опушенность основания & $-\ll-$ & 5 \\
\hline 6 & размер верхушки относительно основания & Маленький & 3 \\
\hline 7 & тип роста верхушки & Открытая & 5 \\
\hline 8 & интенсивность антоциановой окраски верхушки & От слабой до средней & 4 \\
\hline 9 & опушенность верхушки & Слабая & 3 \\
\hline 10 & число корневых бугорков & Много & 7 \\
\hline 11 & длина боковых ростков & Короткие & 3 \\
\hline 12 & $\begin{array}{l}\text { Pастение: } \\
\text { тип облиственности }\end{array}$ & Листовой & 3 \\
\hline 13 & габитус & Полупрямостоячее & 5 \\
\hline 14 & $\begin{array}{l}\text { Стебель: } \\
\text { антоциановая окраска }\end{array}$ & Слабая & 3 \\
\hline 15 & $\begin{array}{l}\text { Лист: } \\
\text { контурный размер }\end{array}$ & Средний & 5 \\
\hline 16 & открытость (силуэт) & Промежуточный & 3 \\
\hline 17 & число вторичных листочков & $\begin{array}{l}\text { От «среднее количество» } \\
\text { до «много» }\end{array}$ & 6 \\
\hline 18 & интенсивность зеленой окраски & Темная & 7 \\
\hline 19 & антоциановая окраска средней жилки верхней стороны & Слабая & 3 \\
\hline 20 & $\begin{array}{l}\text { Вторая пара боковых листочков: } \\
\text { размер: }\end{array}$ & Маленькие & 3 \\
\hline
\end{tabular}


Окончание таблицы

\begin{tabular}{|c|c|c|c|}
\hline $\begin{array}{l}\text { № } \\
\text { П/ח }\end{array}$ & Признак & Степень выраженности & Индекс \\
\hline 21 & ширина по отношению к длине & Средней ширины & 5 \\
\hline 22 & $\begin{array}{l}\text { Bерхушечный и боковой листочек: } \\
\text { частота срастаемости }\end{array}$ & Низкая & 3 \\
\hline 23 & волнистость края & Средняя & 5 \\
\hline 24 & глубина жилок & Мелкие & 3 \\
\hline 25 & глянцевитость верхней стороны & Средняя & 5 \\
\hline 26 & наличие опушения пластинки верхушечной розетки & Имеется & 9 \\
\hline 27 & $\begin{array}{l}\text { Цветок: } \\
\quad \text { антоциановая окраска бутона }\end{array}$ & Средняя & 5 \\
\hline 28 & $\begin{array}{l}\text { Растение: } \\
\text { высота }\end{array}$ & Низкое & 3 \\
\hline 29 & частота (количество цветков) средняя & Мало & 3 \\
\hline 30 & $\begin{array}{l}\text { Соцветие: } \\
\text { размер }\end{array}$ & Маленькое & 3 \\
\hline 31 & антоциановая окраска цветоножки & Средняя & 5 \\
\hline 32 & $\begin{array}{r}\text { Венчик иветка: } \\
\text { размер }\end{array}$ & Средний & 5 \\
\hline 33 & $\begin{array}{l}\text { интенсивность антоциановой окраски внутренней } \\
\text { стороны }\end{array}$ & От средней до сильной & 6 \\
\hline 34 & доля синевы в антоциановой окраске внутренней стороны & Средняя & 2 \\
\hline 35 & размер антоциановой окраски внутренней стороны & Большой & 7 \\
\hline 36 & $\begin{array}{l}\text { Растение: } \\
\quad \text { время созревания } \\
\end{array}$ & От раннего до среднего & 4 \\
\hline 37 & $\begin{array}{l}\text { Клубень: } \\
\text { форма: }\end{array}$ & Овально-округлый & 2 \\
\hline 38 & глубина глазков & Средняя & 5 \\
\hline 39 & окраска кожуры & Желтая & 2 \\
\hline 40 & окраска основания глазка & Желтая & 2 \\
\hline 41 & окраска мякоти & Светло-желтая & 3 \\
\hline 42 & антоциановая окраска кожуры в реакции на свет & Сильная & 7 \\
\hline
\end{tabular}

По результатам Государственного испытания 2018-2019 гг. на сортоучастках Хабаровского, Приморского, Красноярского краев, Читинской и Иркутской областей, Республики Бурятия сорт Зоя показал более высокую продуктивность по сравнению с сортами-стандартами и рекомендован к районированию в Дальневосточном и Восточно-Сибирском регионах.

Ценность сорта Зоя:

стабильная товарная урожайность клубней $(38,0-43,0$ т/га);

высокая экологическая пластичность и адаптированность к колебаниям температурного режима, кратковременному переувлажнению почвы и засухе;

высокая фитофтороустойчивость ботвы и клубней (7-9 баллов);

устойчивость к золотистой цистообразующей и бледной нематоде;

высокая товарность $(93,0-95,0$ \%) и лежкоспособность $(95,0-97,0$ \%) клубней;

компактные гнезда (по 7-14 клубней средней массой 80-110 г);

успешно возделывается на различных почвах Дальнего Востока и Восточной Сибири; длительный период покоя, пригоден для долгого хранения;

высокое для севера Дальнего Востока содержание крахмала (13,0-15,0 \%);

вкусовые качества от хороших до отличных.

Сочетание комплекса хозяйственно ценных признаков с экологической пластичностью и стабильной продуктивностью, независимо от флуктуации погодных факторов, определяет перспективу использования нового сорта Зоя в сельскохозяйственной отрасли Дальнего Востока и Восточной Сибири. 


\section{ЛИТЕРАТУРА}

1. Киру С.Д., Жигадло Т.Э. Оценка исходного материала для селекции ранних сортов картофеля в северных условиях // Методы и технологии в селекции растений и растениеводства: материалы Междунар. науч.-практ. конф. Киров: НИИСХ Северо-Востока, 2015. С. 241-245.

2. Кожемякин В.С. Состояние отрасли картофелеводства в Южно-Уральском регионе РФ // Вопросы картофелеводства: науч. труды ВНИИКХ. М., 1998. С. 74-78.

3. Кордабовский В.Ю. Климатическое и биологическое обоснование селекции картофеля в Магаданской области // Теор. и прикл. проблемы АПК. 2017. № 4 (33). С. 32-35.

4. Охлопкова П.П. Исследования по картофелю в условиях Якутии // Сб. науч. тр. Россельхозакадемия. Дальневост. регион. центр. Камч. НИИСХ. Владивосток: Дальнаука, 2010. С. 57-60.

5. Пискун Г.И. Характер проявления свойств адаптивности и стабильности у гибридного потомства картофеля в зависимости от исходных форм // Материалы Междунар. юбилейной науч.-практ. конф., посвящ. 75-летию Института картофелеводства НАН Беларуси. Минск: Мерлит, 2003. Ч. 1. С. 132-137.

6. Сафонова О.В. Изучение изменчивости хозяйственно ценных признаков картофеля при сортоиспытании в различных экологических условиях Горного Алтая: автореф. дис. ... канд. с.-х. наук. Новосибирск, 2005. 195 с.

7. Симаков Е.А., Яшина И.М., Склярова Н.П. Эффективность селекционного отбора при оценке гибридных популяций картофеля в различных эколого-географических условиях // Материалы Междунар. юбилейной науч.-практ. конф., посвящ. 75-летию Института картофелеводства НАН Беларуси. Минск: Мерлит, 2003. Ч. 1 C. $92-100$.

8. Шабанов А.Э., Анисимов Б.В., Киселев А.И. и др. Сравнительная оценка продуктивности и показателей качества сортов картофеля российской и зарубежной селекции // Картофелеводство: материалы Междунар. науч.-практ. конф. «Развитие новых технологий селекции и создание отечественного конкурентоспособного семенного фонда картофеля». М.: ФГБНУ ВНИИКХ, 2016. С. 117-125.

9. Яшина И.М. Значение сорта в современных технологиях производства картофеля // Актуальные проблемы современной индустрии производства картофеля. Чебоксары: КУП ЧР «Агро-Инновации», 2010. С. 41-45. 